\title{
膜構造物における滑雪時の性状に関する研究 STUDY ON THE PROPERTY OF SNOW WHEN SLIDING OFF MEMBRANE STRUCTURE ROOF
}

\author{
山口英治*1, 苫米地 司*2, 山田利行*3, 中島 肇*4, 伊東敏幸*5, 星野政幸*6 \\ Hideharu YAMAGUCHI, Tsukasa TOMABECHI, Toshiyuki YAMADA, \\ Hajime NAKAJIMA, Toshiyuki ITO and Masayuki HOSHINO
}

\begin{abstract}
For the purpose of snow disposal on the roof of membrane structure, it is necessary to investigate on the snow-slide after the fall from the roof. The purpose of the experimental study is to obtain basic data concerning with disposal method after the fall from the roof. This experiment was done using the outdoor model apparatus. This study is investigated on the fall distance and fall dispersion of the snow from the roof under various conditions. As a result, it became clear the fact which sliding and falling distance of the snow was influenced on the snow load. Furthermore, it was proved the existance not only kinetic friction force but also viscostic resisting force between the snow and roof when it is sliding.
\end{abstract}

Keywords : snow on the roof, membrane structure, viscostic resisting force, kinetic friction force 屋根雪, 膜構造物, 粘性抵抗力, 動摩擦抵抗力

\section{1.はじめに}

1988 年に東京ドームが建設されて以来, 四ふっ化エ チレンコーティングガラス繊維布 (以下「膜材」という。) を用いた膜構造物が, 短期間の仮設的な特殊施設から恒 久建築物として推移してきた。恒久建築物としての膜構 造物の数は, 大規模から小規模に至るまで数百以上建設 されている”。膜材は，透過性に優れているために明る い室内空間を得ることができ，室内空間を「屋外に近い 空間」としてイメージできる。このような「空間イメー ジ」や「乾いた土のグラウンド」を期待して, 近年, 雪 の少ない太平洋沿岸地域ばかりでなく, 1 年の半分近く を雪に閉じ込められる北海道，青森県および秋田県など の雪国にも数多くの膜構造物が建設されている”。

しかし，膜材の透過性は，わずかな積雪でも損なわれ るため, 雪国に膜構造物を建設する場合には屋根雪処理 方法が大きな問題となる。この屋根雪処理に関する研究 は, 膜構造物が注目され始めた 1980 年代には融雪処理 の考え方が中心であったが，1990 年代に入ると滑雪性
状に優れた膜材の特性を生かして融雪させながら滑雪処 理する考え方に移行している2) 6)。このように，屋根雪 を滑雪させる場合には，滑雪後の飛距離や飛散範囲など を十分に考慮する必要がある。これらの屋根雪の性状は, 建築物の配置計画や防災計画に大きく影響を与え, 雪国 の建築物を考える場合の重要な要因となる。さらにこ れらの屋根雪の性状は大スパン構造物になるほど大きな 問題となる。しかし, 現状では屋根雪の滑雪後の性状に 関する研究の蓄積が極めて少ない状況にある。

このような背景から，本研究では屋根雪の滑雪飛距離 や飛散範囲に関する基礎資料を得ることを目的に，屋根 莫材に膜材を用いた滑雪装置で屋外モデル実験を実施 し, 屋根雪の滑雪後の飛距離や飛散範囲を検討した。

\section{2. 実験方法}

\section{1 実験装置}

写真一1に，屋外に設置した実験装置の概要を示す。 本奏験装置は, 北海道工業大学内の屋上（高さ $13.1 \mathrm{~m}$ )

\footnotetext{
*1 太陽工業 (株) 技術本部設計部（当時 北海道工業大 Design Division, Taiyo Kogyo Corporation, M. Eng. 学 大学院生) · 修士 (工学)

*2 北海道工業大学建築工学科 助教授・博士 (工.学)

*3 清水建設 (株) 設計本部

*4 清水建設 (株) 技術開発本部・修士 (工学)

*5 北海道工業大学建築工学科 助手

*6 北海道工業大学建築工学科”教授・博士 (工学)

Assoc. Prof., Dept. of Architecture, Hokkaido Institute of Technology, Dr. Eng.

Shimizu Corporation deputy General Eng.

Shimizu Corporation, M. Eng.

Research Assoc., Dept. of Architecture, Hokkaido Institute of Technology

Prof., Dept. of Architecture, Hokkaido Institute of Technology, Dr. Eng.
} 
に設置した滑雪装置と地上に設置した滑雪後の挙動を観 察するための黒板（幅 $9 \mathrm{~m} \times$ 高さ $3.6 \mathrm{~m}$ ) で構成されて いる。図一 1 に，屋上に設置した滑雪装置の概要を示す。 この滑雪装置は, 滑動挙動の観察, 滑雪角度および滑雪 速度の测定が容易なことから傾斜平板法を採用した 傾斜台（長さ $8 \mathrm{~m}$, 幅 $1 \mathrm{~m}$ ) の両端には，写真一 2 に示 すように速度測定用光センサー(読み取り精度 $1 / 100$ 秒) が, $4.25 \mathrm{~m}$ 間隔で 2 個取り付けてある。光センサーの 設置位置は，本センサーが測定誤差を少なくするために $4 \mathrm{~m}$ 以上の測定間隔が必要であることと, 実験時の安 全性を考慮して決定した。なお，傾斜台に張り付けた膜 材は四ふっ化樹脂エチレンコーティングガラス繊維布で ある。

\section{2 滑走モデル}

滑走モデル（以下「雪モデル」という。）は，屋上の 積雪 (全層平均積雪密度 $0.24-0.35 \mathrm{~g} / \mathrm{cm}^{3}$ ) を木製枠 (内 径：縦 $87 \times$ 横 $82 \times$ 高さ $30 \mathrm{~cm}$ ) 内に骨材了るい分け用 の $15 \mathrm{~mm}$ ふるいでふるいながら堆積させてブロック状 に作製した。この雪モデルの高さは $10,20,30 \mathrm{~cm} の$ 3 種類とした。なお，滑雪開始前にスノーサンプラーで

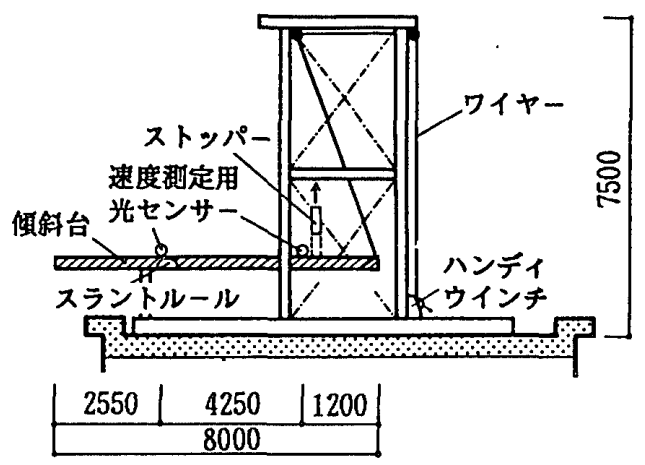

図一1 滑雪装置の概要

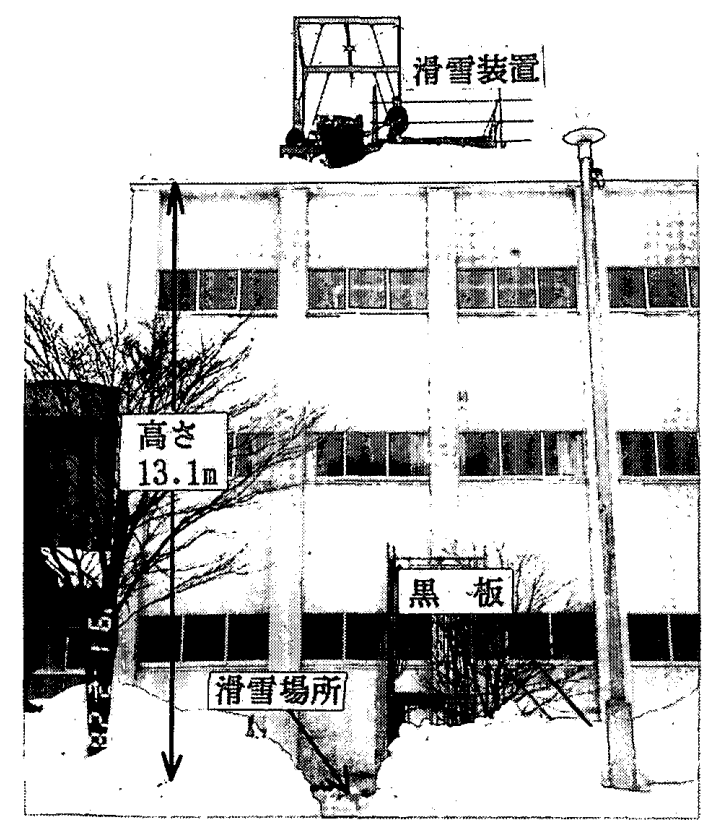

写真一1 実験装置の概要
雪モデルの積雪密度, 秋田谷式含水率計で含水率を測定 した。

\section{3 実験シリーズ}

滑雪実験は，滑走距離を $3.3 \mathrm{~m}, 5.3 \mathrm{~m}, 7 \mathrm{~m}$ の 3 種 類とし，表一 1 に示す条件で実施した。同表のように， 滑走距離を一定にして滑雪角度と積雪深とを変えた 8 種 類の実験と積雪深を一定にして滑雪角度と滑走距離とを 変えた 6 種類の実験を実施した。

\section{4 測定方法}

前述の雪モデルを傾斜台に滑走距離が所定の距離 $(3.3 ， 5.3 ， 7 \mathrm{~m})$ になるように設置し，所定の角度に なるまで滑雪しないように雪モデル前方にストッパーを 取り付けた。滑走距離は，雪モデルの最先端から傾斜台 の最先端部までの距離とした。その後, ハンディウィン チを所定の角度に達するまで巻き上げて，ストッパーを 取り外して滑雪させた。雪モデルの滑雪速度は, 傾斜台 の両端に取り付てある速度測定用光センサーで測定し た。滑雪速度 $V_{1}(\mathrm{~m} / \mathrm{s})$ は, $V_{1}=L_{1} / t\left(V_{1}\right.$ : センサー間 の距離， $t$ : センサー間の滑雪時間) より求めた。滑雪 後の飛距離や飛散範囲は, 黒板の前方に設置したビデオ カメラで観測した。いずれの実験も同一条件で 3 回実施 した。なお，滑雪後の観測および測定を正確にするため， 雪面に希薄した青色のインク溶液を噴第した。

表一1実験シリーズ

\begin{tabular}{|c|c|c|c|c|c|c|c|c|c|c|}
\hline \multicolumn{2}{|c|}{ 皘雪澡 (C口) } & \multicolumn{3}{|c|}{10} & \multicolumn{3}{|c|}{20} & \multicolumn{3}{|c|}{30} \\
\hline \multicolumn{2}{|c|}{ 皘雪重量 $\left(\mathrm{kg} / \mathrm{m}^{2}\right)$} & \multicolumn{3}{|c|}{$25 \sim 35$} & \multicolumn{3}{|c|}{$50 \sim 70$} & \multicolumn{3}{|c|}{$75 \sim 105$} \\
\hline \multicolumn{2}{|c|}{ 滑雪角度 $\left(^{\circ}\right)$} & 15 & 20 & 25 & 15 & 20 & 25 & 15 & 20 & 25 \\
\hline \multirow{3}{*}{$\begin{array}{r}\text { 滑雪距髅 } \\
\text { (n) }\end{array}$} & 3.3 & - & - & - & - & - & - & 0 & - & 0 \\
\hline & 5.3 & - & - & - & - & - & - & - & - & 0 \\
\hline & 7.0 & 0 & 0 & 0 & 0 & 9 & - & 0 & 0 & - \\
\hline
\end{tabular}

注）表中の○は実騟中の平均外気渴が $-5^{\circ} \mathrm{C}$ 前後，○は実臨中 の平均外気温が-2C前後である。

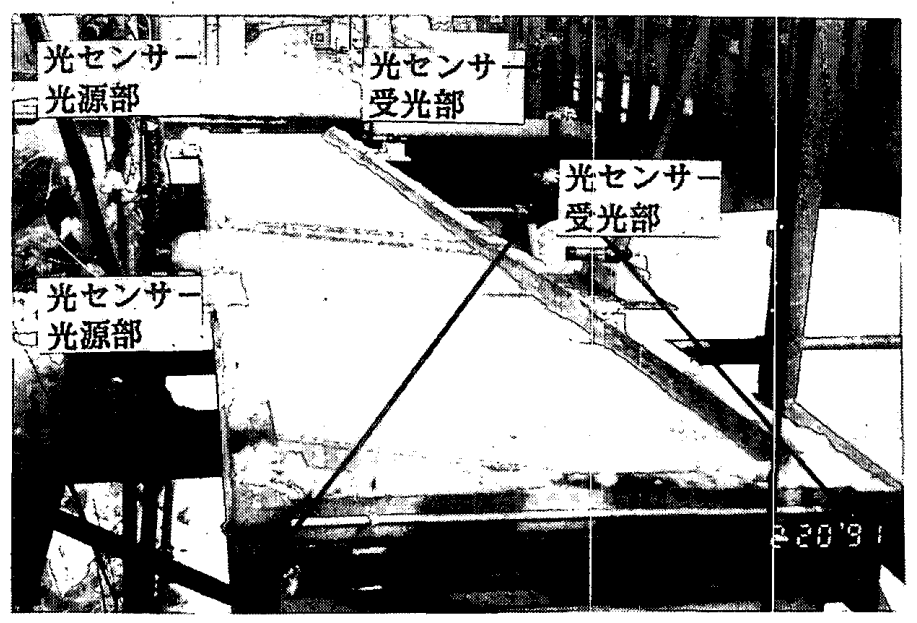

写真一2 傾斜台の概要 


\section{3. 実験結果}

雪モデルの滑走中および滑雪後の挙動を観察すると, 雪モデルは，ブロック形状を保ちながら大きな摇れもな く一気に滑走して落下した。滑雪後は, 雪モデルの隅角 部で多少の分離がみられたが，大きく分離することなく ブロック形状を保ちながら雪面に衝突し，前後に大きく 飛散した。これらの実験結果を基に，滑雪飛距離，滑雪 抵抗力および滑雪後の性状について検討すると，以下の ようになる。なお，実験に用いた雪モデルの密度は $0.25 \sim 0.35 \mathrm{~g} / \mathrm{cm}^{3}$, 含水率は 5〜9\%でしまり雪に近似 した状態であった。

\section{1 滑雪飛距離}

これまでの屋根雪の滑雪飛距離に関する研究では, 動 摩擦抵抗力のみを考慮した質点の運動法則に従い下式で 飛距離を求めている ${ }^{8), 9) 。 ~}$

$$
\begin{aligned}
& D=V \cdot \cos \theta\left(\sqrt{\left(V \cdot \sin \theta \cdot g^{-1}\right)^{2}+2 H \cdot g^{-1}}\right. \\
& \left.-V \cdot \sin \theta \cdot g^{-1}\right) \\
& \text { ただし， } V=\sqrt{2 \cdot g \cdot L\left(\sin \theta-\mu_{k} \cdot \cos \theta\right)} \\
& \mu_{k}=(g \cdot \sin \theta-\alpha) \cdot(g \cdot \cos \theta)^{-1} \\
& \text { ここに, } D \text { : 滑雪飛距離 }(\mathrm{m}) \quad \theta \text { : 滑雪角度 }\left({ }^{\circ}\right) \\
& V: \text { 飛び出し速度 }(\mathrm{m} / \mathrm{s}) \quad H: \text { 軒高 }(\mathrm{m}) \\
& L \text { : 滑走距離 }(\mathrm{m}) \quad \mu_{k} \text { : 動摩擦係数 } \\
& g: \text { 重力加速度 }\left(\mathrm{m} / \mathrm{s}^{2}\right) \quad \alpha: \text { 加速度 }\left(\mathrm{m} / \mathrm{s}^{2}\right)
\end{aligned}
$$

ここで, 滑走距離 $7 \mathrm{~m}$ の場合における式（1）から得 られた飛距離と実测値とを対比すると，図一2 2 なる。

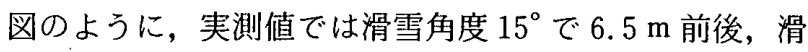
雪角度 $20^{\circ}$ で $8 \mathrm{~m}$ 前後の飛距離となり, 滑雪角度の増加 に伴い滑雪飛距離が顕著に増加する。しかし, 滑雪角度 $25^{\circ}$ になると $8.5 \mathrm{~m}$ 前後の飛距離となり, 緩慢な增加傾 向を示す。これらの実测值は，図中の実線で示す $\mu_{k}=0$ と $\mu_{k}=0.2$ を用いて算出した飛距離の計算値の間に位置 しているが，滑雪角度が低いほど計算值との差が大きく なり，計算值と必ずしも一致する傾向は見られない。各 滑雪角度ごとの飛距離をみると, 積雪重量が大きいほよ゙ 飛距離が大きくなる傾向にあり, 各角度とも滑走距離の $30 \%$ 程度に相当する $2 \mathrm{~m}$ 前後のバラッキがみられる。

図一 3 に，積雪深が $30 \mathrm{~cm}$ (積雪重量 $75 \sim 105 \mathrm{~kg} / \mathrm{m}^{2}$ ) における滑走距離と滑雪飛距離との関係を示す。図中に は, 前述の式 (1) から得られる滑雪飛距離の值を合わ せて示してある。図のように，滑雪飛距離の実測值は滑 走距離の増加に伴い緩慢な増加傾向を示す。これに対し， 計算値は滑走距離の増加に伴い急激な増加傾向を示し, 実測値と計算值とでは大きく異なる傾向を示す。これら の実測値と計算値との差をみると, 滑走距離が $3.3 \mathrm{~m}$ では実測㒹が計算值を上回る。逆に，滑走距離が $7.0 \mathrm{~m}$ になると計算值が夷测值を上回り，さらに滑走距離が長 くなると両者の差が大きくなる傾向を示す。

したがって，滑走距離が長くなる大スパン構造物など
には式（1）を適忍できない。これらのことから，滑雪 飛距離の算出には，これまで用いられていた運動法則式 だけでは不十分であり，動摩擦抵抗力以外の抵抗力も考 慮することが必要と考える。

\section{2 滑雪抵抗力}

前述のように，滑雪飛距離の算出には動摩擦抵抗力を 考慮するだけでは不十分である。さらに，これまでの屋 根雪の滑雪性状に関する研究によると, 滑雪抵抗力とし て動摩擦抵抗力のほかに粘性抵抗力もあることが指摘さ れている(10),11)。これらの考え方から判断すると，滑雪飛 距離は動摩擦抵抗力と粘性抵抗力とを同時にとらえて検 討する必要がある。ここで，滑走時の屋根雪に作用する 抵抗力は図一4のように仮定できる。滑雪抵抗力 $R$ $\left(\mathrm{kg} / \mathrm{m}^{2}\right)$ は式 (4) に示すように, 粘性抵抗力と動摩擦 抵抗力との和となる。この関係を用いて屋根雪の飛跡を 求めると式（5）となる。式（5）功 $R$ を求めると 式（6）となる。

$$
\begin{aligned}
& R=C+\mu_{k} \cdot M \cdot \cos \theta \\
& \left(M\left(4 \cdot L(M \cdot \sin \theta-R) \cos ^{2} \theta\right)^{-1}\right) D^{2} \\
& +\tan \theta \cdot D-H=0 \text {. } \\
& R=M\left(\sin \theta-\left(D^{2}\left(4 \cdot L \cdot \cos ^{2} \theta(H-D \cdot \tan \theta)^{-1}\right)\right)\right) \\
& \text { ここに, } \mu_{k} \text { : 動摩擦係数 } \quad H \text { : 軒高 }(\mathrm{m})
\end{aligned}
$$

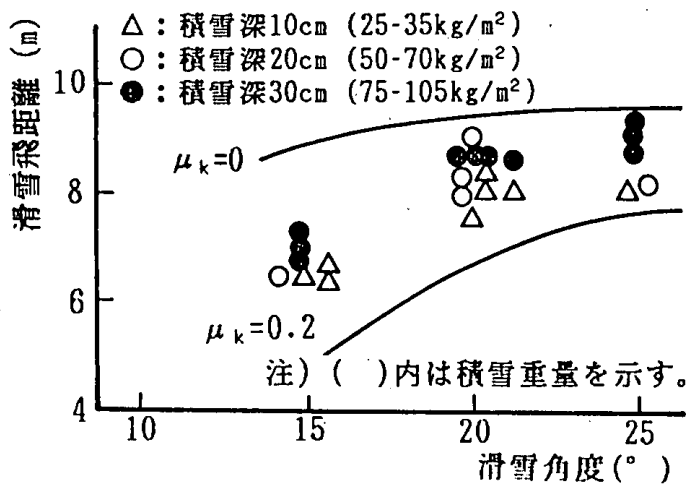

図一2 滑雪飛距離と滑雪角度との関係(滑走距離 $7 \mathrm{~m}$ との関係)

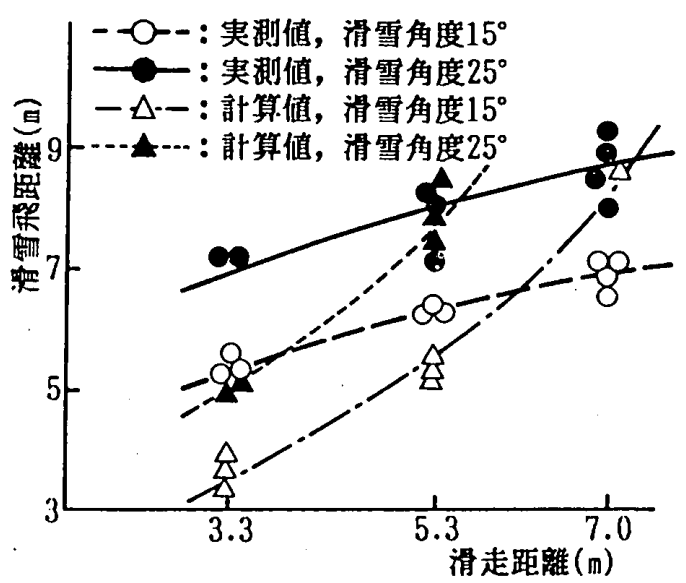

図一3滑雪飛距離と滑走距離との関係（積雪染 $30 \mathrm{~cm}$, 積雪重 量 $75-105 \mathrm{~kg} / \mathrm{m}^{2}$ ) 

$\theta:$ 滑雪角度 $\left(^{\circ}\right)$
$D:$ 滑雪飛距離 $(\mathrm{m})$
$L$ : 滑走距離 $(\mathrm{m})$
$C:$ 粘性抵抗力 $\left(\mathrm{kg} / \cdot \mathrm{m}^{2}\right)$
$M:$ 積雪重量 $\left(\mathrm{kg} / \mathrm{m}^{2}\right)$

ここで，本実験結果を用いて式（6）加得られる $R$ と $M \cdot \cos \theta$ との関係をみると, 図一 5 となる。図の ように，いずれの滑雪角度においても $M \cdot \cos \theta$ の増加 に伴い $R$ の值は大きくなる傾向を示し, 図中の式で近 似できる。この回帰式は式（4）に対応し, 式の傾きが $\mu_{k}$, 切片が $C$ に相当する。これらの回帰式から得られ た動摩擦係数および粘性抵抗力の関係をみると, 図一6 となる。図のように, 粘性抵抗力 $C$ は滑雪角度の増加 に伴い増加する傾向を示し, 逆に動摩擦係数は滑雪角度 の増加に伴い減少する傾向を示す。これらの值を遠藤ら のフッ素樹脂塗装鋼板などを用いた実験結果（C=2.5 $\left.\sim 3 \mathrm{~kg} / \mathrm{m}^{2}, \mu_{k}=0.13 \sim 0.15\right)$ と対比すると, 両者とも 本実験結果の方が比較的小さな值を示し, 膜材が滑雪し

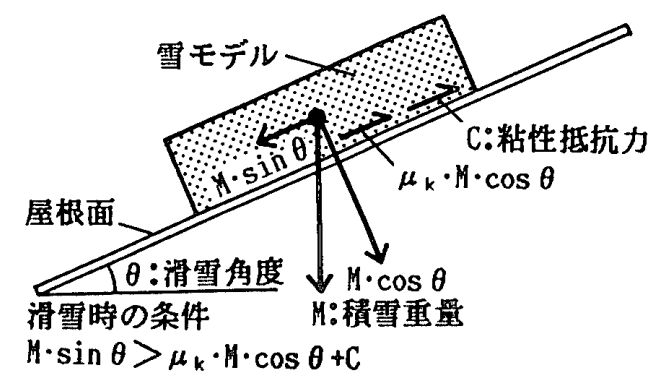

図-4 滑雪時の屋根雪に作用する力の釣合い

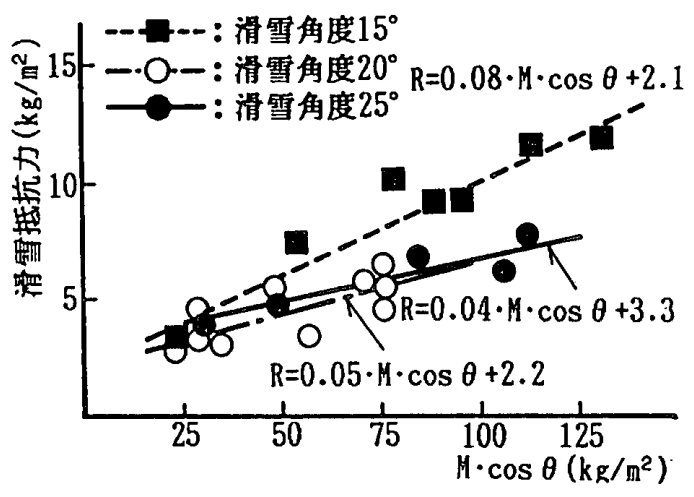

図一 5 滑雪距離抵抗力と $M \cos \theta$ との関係

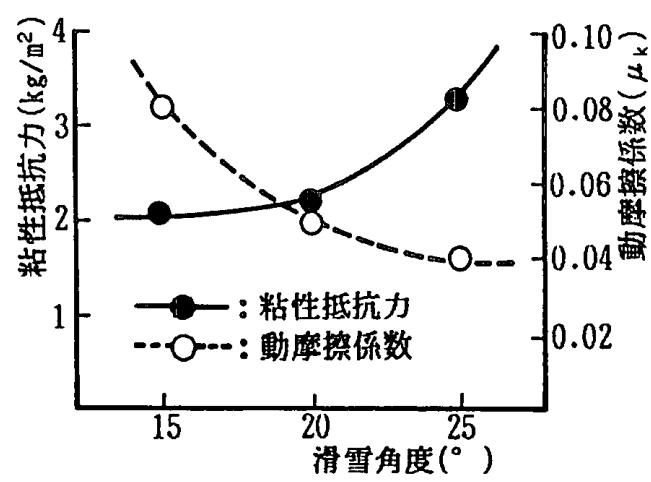

図-6 粘性抵抗力, 動摩擦係数と滑雪角度との関係
やすい屋根苒材であることを示している"1!。滑雪直後の 膜面上を観察すると，滑走時の摩擦熱によって発生した と考えられる微量の水膜がみられる。前述の膜材と雪モ デルとの界面に働く粘性抵抗力は，この水膜によって発 生していると考えられる。膜材と雪モデルとの界面に生 ずる水膜の厚さは粘性流体の法則に従うと下式で求めら れる ${ }^{12) 。 ~}$

$$
C=\mu_{c} \cdot A \cdot \Delta V \cdot \Delta Y^{-1}
$$

ここに, $\mu_{c}:$ 水の粘性係数 $\left(\mathrm{kgf} \cdot \mathrm{s} / \mathrm{m}^{2}\right)$

$A:$ 膜材と雪モデルとの見かけ状の接触面積 $\left(\mathrm{m}^{2}\right)$

$\Delta Y:$ 膜材と雪モデルとの界面の微少な距離 $(\mathrm{m})$ $\Delta V:$ 雪モデルが傾斜台を滑雪する時の速度 $(\mathrm{m} / \mathrm{s})$

ここで, 本実験結果で得られた粘性抵抗力から膜材と雪 モデルとの界面の微小な距離 $\Delta Y$ を求めると, $0.13 〜$ $0.28 \mathrm{~mm}$ の薄い厚さとなる。なお，水の粘性係数は, 1 atm, $0^{\circ} \mathrm{C}$ における水の粘性係数 $\left(182.7 \times 10^{-6} \mathrm{kgf} \cdot \mathrm{s} / \mathrm{m}^{2}\right)$ を用いた。すなわち, 屋根雪の滑雪に必要な水分量は, この薄い微小空間に介在していることに゙る。

このように，滑雪抵抗力として動摩擦抵抗力に微量の 水膜によって発生していると考えられる粘性抵抗力とが 作用している。ここで，各滑雪角度における両皆の抵抗 力の作用度合いをみると図一7となる。図のように，動 摩擦抵抗力は積雪重量の増加に伴い大きくなり, 滑雪角 度の増加に伴い減少する。この減少傾向は積雪重量が大 きいほど顕著である。これに対し，粘性抵抗力は滑雪角 度の増加に伴い増加し，両者は相反する傾向を示す。こ れらの傾向をみると, 滑雪抵抗力として滑雪角度 $15^{\circ}$ で は動摩擦抵抗力が大きく作用し, 滑雪角度 $25^{\circ}$ では粘性 抵抗力が大きく作用している。すなわち, 低い角度では 動摩擦抵抗力が大きく作用し, 逆に角度の増加に伴い粘 性抵抗力の影響が大きくなる。

次に，滑雪抵抗力と滑雪角度との関係をみると図-8 となる。図のように, 積雪重量 $60 \mathrm{~kg} / \mathrm{m}^{2}$ を超える範囲 では滑雪角度 $20^{\circ}, 25^{\circ}$ に比べて滑雪角度 $15^{\circ}$ の滑雪抵

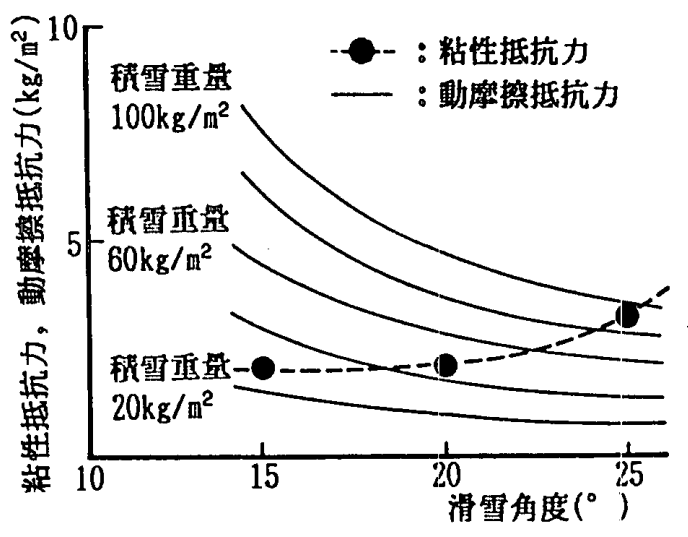

図一7 粘性抵抗力, 動摩擦抵抗力と滑雪角度との関係 


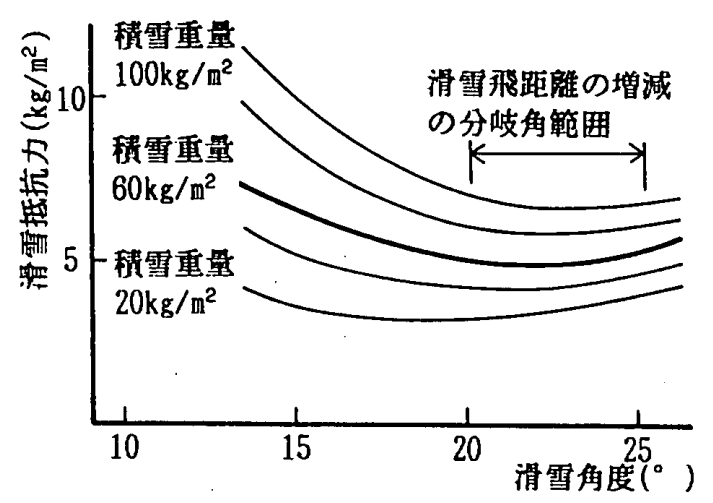

図一8 滑雪抵抗力と滑雪角度との関係

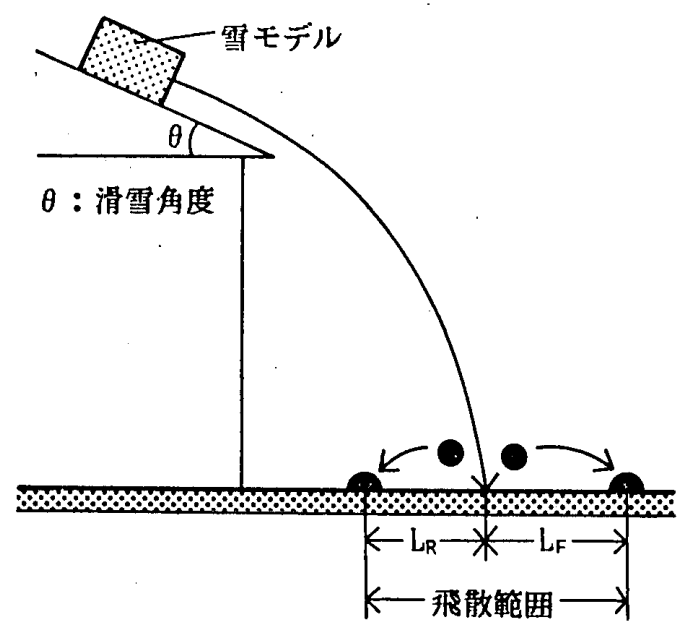

図一9 飛散範囲の模式図

抗力が大きくなる。これに対して, 積雪重量 $60 \mathrm{~kg} / \mathrm{m}^{2}$ 未満の範囲では滑雪角度による滑雪抵抗力の差異がみら れない。また, 滑雪角度 $20^{\circ}, 25^{\circ}$ では, いずれの積雪 重量においても滑雪抵抗力が同程度の值を示す。した がって,この範囲が積雪飛距離の最大值を示す増減の分 岐角になると考えられる。

\section{3 屋根雪の滑雪後の飛散}

滑雪飛距離を検討する場合, 屋根雪は滑雪後に飛散す ることから滑雪飛距離に飛散の範囲を加える必要があ る。滑走距離 $7 \mathrm{~m}$ の実験で図一9に示す $L_{F}$ と $L_{R}$ を測 定して飛散範囲を検討した。なお，落下場所はアスファ ルト上に 3 4 cm 程度積雪させた状態とした。飛散距 離と滑雪角度との関係をみると，図一10 となる。図の ように，いずれの積雪重量においても滑雪角度の増加に 伴い飛散範囲が増加する傾向を示す。各滑雪角度ごとの $L_{F}$ と $L_{R}$ とを対比すると， $L_{F}$ が $L_{R}$ の 1.5 2. 3 倍程度 となり常に $L_{F}$ の方が大きい値を示す。この傾向は積雪 重量が大きいほど顕著である。さらに，この飛散距離は 滑雪角度 $20^{\circ}$ を超えると滑雪飛距離よりも大きくなる場 合がある。なお，屋根雪の落下位置に $30 \mathrm{~cm}$ 程度の新 雪（全層平均積雪密度 $0.15 \mathrm{~g} / \mathrm{cm}^{3}$ 程度）がある場合に おける予備実験結果をみると, 飛散距離が小さくなるこ とから落下位置の積雪状況によっても飛散距離が大きく

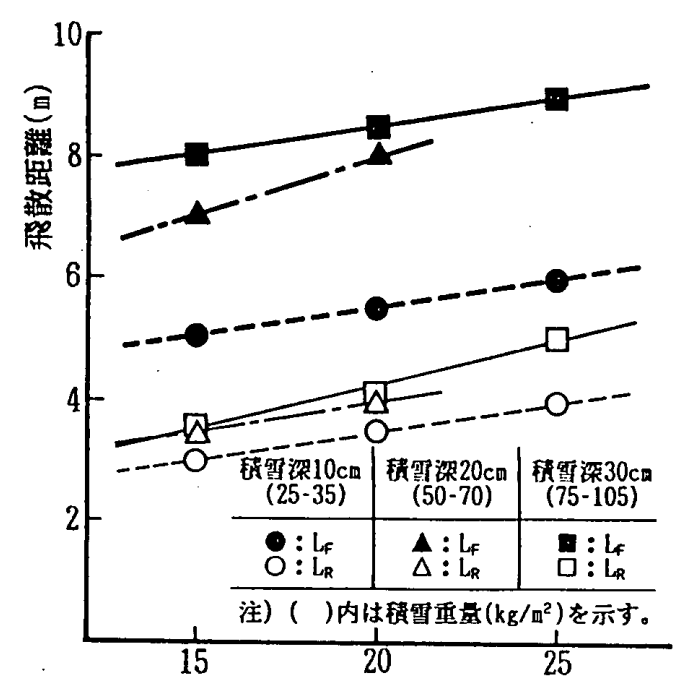

滑雪角度 $\left(^{\circ}\right)$

図-10 飛散距離と滑雪角度との関係

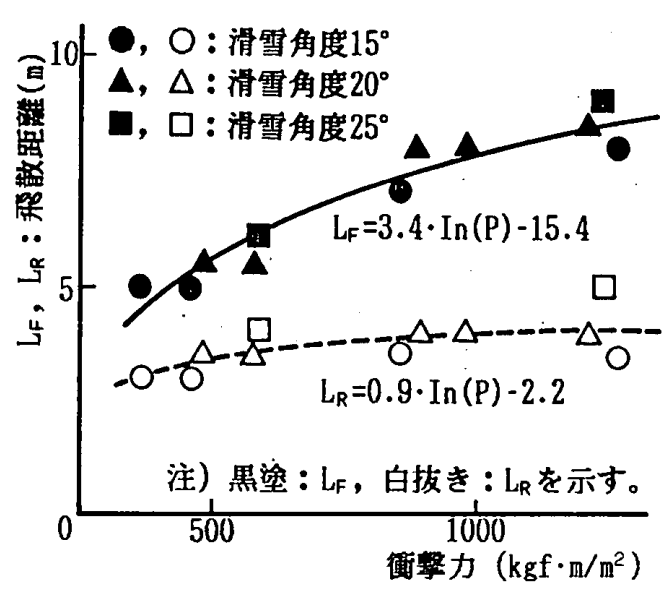

図一11 飛散距離と衝撃力との関係

異なると考える。

このように，飛散距離は積雪重量によって大きく異な ることから，屋根雪が雪面に衝突するときの衝撃力の影 響を大きく受けていると考えられる。ここで，力学的工 ネルギー保存の法則から求められる衝突時の運動エネル ギ一量を衝撃力として，この衝撃力と $L_{F}$ との関係をみ ると図一11 となる。図のように，衝撃力の増加に伴い $L_{F}$ が大きくなる傾向を示し，図中の式で近似できる。 したがって, 飛散距離は衝撃力を考慮して算出しなけれ ばならない。

\section{4. 滑雪飛距離および飛散距離の算出法}

前述のように, 滑雪飛距離は粘性抵抗力之動摩擦係数 の影響を大きく受け，飛散距離は落下時の衝撃力の影響 を大きく受けることが明らかとなった。これらの要因を 考慮した滑雪角度 $25^{\circ}$ 程度までの滑雪飛距離と飛散距離 の算出法を整理すると以下のようになる。

滑雪飛距離 $D$ は下式で求められる。

$$
\begin{aligned}
D= & V \cdot \cos \theta\left(\sqrt{\left(V \cdot \sin \theta \cdot g^{-1}\right)^{2}+2 \cdot H \cdot g^{-1}}\right. \\
& \left.-V \cdot \sin \theta \cdot g^{-1}\right)
\end{aligned}
$$


ただし，

$$
V=\sqrt{\left(2 \cdot g \cdot L\left(M \cdot \sin \theta-\mu_{k} \cdot M \cdot \cos \theta-C\right)\right) \cdot M^{-1}}
$$

ここに, $D:$ 滑雪飛距離 $(\mathrm{m}) M:$ 積雪重量 $\left(\mathrm{kg} / \mathrm{m}^{2}\right)$

$$
\theta: \text { 勾配 }\left({ }^{\circ}\right) \quad V: \text { 飛び出し速度 }(\mathrm{m} / \mathrm{s})
$$

$L:$ 滑走距離 $(\mathrm{m}) \quad H:$ 軒高 $(\mathrm{m})$

$g:$ 重力加速度 $\left(\mathrm{m} / \mathrm{s}^{2}\right)$

$\mu_{k}:$ 図一6 から得られる動摩擦係数

$C:$ 図一6 加得られる粘性抵抗力

滑雪後の飛散距離 $L_{F}$ は下式で求められる。

$$
L_{F}=3.4 \cdot \ln (P)-15.4
$$

ここに, $P$ : 衝撃力 $\left(\mathrm{kgf} \cdot \mathrm{m} / \mathrm{m}^{2}\right)$

\section{5.まとめ}

本研究では，膜構造物を対象とした屋根雪の滑雪後の 飛距離や飛散範囲について屋外実験で検討した。その結 果, 滑雪飛距離は粘性抵抗力と動摩擦係数の影響を大き く受けることが明らかとなった。したがって, 滑雪飛距 離は動摩擦抵抗力と粘性抵抗力とを同時にとらえて検討 する必要がある。さらに, 落下後の飛散範囲は衝撃力の 増加に伴い大きくなる傾向を示すことから，衝撃力を考 慮して算出する必要がある。本実験結果から，これらの 要因を考虑した滑雪飛距離や飛散距離の算出法に関する 基礎的な資料を得ることができた。なお，本実験では最 も単純な屋根形状を想定して実施したため, 滑雪飛距離 や飛散に関する一般式を得るためには屋根形状の影響や 膜面の温度条件などの検討が必要である。

\section{参考文献}

1）新建築社企画編集部：膜構造デザインの系譜,(株) 新建
築社, 1990.9

2）川島 実ほか 3 名: 空気膜構造 (エアサポートドーム) 融雪実験 第 1 報, 第 2 報, 日本建築学会大会学術講演 梗概集，pp. 787 790，1984. 10

3）宮川保之ほか 1 名：空気膜構造棣に関する実験・研究そ の 8 大型模型による融雪実験, 日本建築学会大会学術 講演梗概集, pp. 629 630, 1985.10

4) 西 安信ほか 2 名：空気膜構造における融雪実験その 2 , 日本建築学会大会学術講演梗概集, pp. 895 896, 1986.8

5）苫米地司ほか 3 名：膜構造物の犚根雪処理に関する基礎 的研究, 日本建築学会構造系諭文報告集, 第 426 号, 1991.8

6）大塚清敏ほか 5 名：膜構造の雪好理に関する研究，(社） 日本膜構造協会, 膜構造研究論文集' 90 , No. 4, pp. 55 $68,1990.12$

7）渡辺正朋 : 屋根蒀材の滑雪特性に関する基礎的研究, 東 北大学学位論文, pp. $65 \sim 73,1990.6$

8）阿部 修：大型㑯斜屋根におけ名軒下落雪の堆積形状, 平成 2 年度日本雪水学会全国大会講演予稿集, p. 7, 1990.6

9）渡辺正朋：屋根葺材の滑雪特性に関する基礎的研究, 東 北大学学位論文, pp. 155 168, 1990.6

10）前田博司ほか 1 名：屋根の雪荷重に関する基㗪的研究, 日本建築学会大会学術講演梗概集, pp. $559 \sim 560$, 1975.6

11）遠藤八十一ほか 6 名: 屋根雪の滑落条件之飛距離, 寒地 技術シンポジウム'88講演論文集, pp. 220-225, 1988. 11

12）生井武文：流れの力学, (株) コロナ社, pp. 3〜 , 1976.10

(1991 年 9 月 10 日原稿受理, 1992 年 4 月 13 日採用決定) 